\title{
A STUDY ON THE INHIBITORY EFFECT OF POLYSACCHARIDES FROM RADIX RANUNCULUS TERNATI ON HUMAN BREAST CANCER MCF-7 CELL LINES
}

\author{
De-Li Sun ${ }^{1 *}$, Han-Bing Xie ${ }^{1}$, Yun-Zhan Xia ${ }^{1}$ \\ ${ }^{1}$ People's Hospital of Zhengzhou, Huanghe Road 33, Zhengzhou 450000, Henan Province, China \\ *E-mail: sundeli291@163.com
}

\begin{abstract}
The objective of this paper was to study the in vitro anti-breast cancer activity of polysaccharides from Radix ranunculus ternati. Different concentrations of polysaccharide extracts were selected, and MTT assay and flow cytometry (FCM) were used to investigate their growth-inhibitory and apoptosis-inducing effects on human breast cancer MCF-7 cell lines. Radix ranunculus ternati polysaccharides had varying degrees of effects on the growth of human breast cancer MCF-7 cell lines, and the differences were significant compared with the blank control group. FCM showed that the polysaccharides can induce apoptosis. In addition, it can also enhance NK cell activity. Radix ranunculus ternati polysaccharides have a relatively good in- vitro anti-breast cancer activity.
\end{abstract}

Keywords: Radix ranunculus ternati; polysaccharides; MCF-7

\section{Introduction}

Radix ranunculus ternati is the dried root tuber of Ranunculus ternatus Thunb. in the family Ranunculaceae (Pharmacopoeia of the People's Republic of China, 2000), which is also known as Sansancao (Zhejiang), Maozhuaercao (Henan), Maozhuazi (Henan), Yajiaoban (Anhui) and Jinhuacao (Guangxi) (Xie et al., 1996; Yu et al., 1996). Originally, it is mainly grown in Xinyang, Hengchuan and Xixian of Xinyang Region as well as Zhengyang and Queshan of Zhumadian Region in Henan. Now, it is distributed in the Yangtze River's mid and downstream provinces, as well as Zhejiang, Jiangsu, Anhui, Jiangxi, Taiwan, Guangxi, Henan, Hubei, Hunan, Sichuan, Yunnan and Guizhou provinces (Flora of China, 1979; Chinese Materia Medica, 1982; National Herbal Compendium 1982). Radix ranunculus ternati has a very complex chemical composition. According to the measurement of the Institute of Materia Medica of Chinese Academy of Medical Sciences, Radix ranunculus ternati contains $16 \%$ of sugar, $1.2 \%$ of oil, and very little plant alkaloids (Yang et al., 1998). Japanese scholars have separated and identified monosaccharide constituents such as glucose, arabinose and galactose from aerial parts of its variant Ranunculus ternatus varglaber (Iriky, 1972; Iriky, 1975). After years of clinical validation, it was verified that Radix ranunculus ternati has relatively good effects on malignant lymphomas, thyroid tumors and breast neoplasms (Zhou et al., 1997; Wu et al., 1997; Yang et al., 1981), but the anti-tumor effective constituents of Radix ranunculus ternati and their mechanisms of action are still unclear. In view of this, Radix ranunculus ternati is often decocted with water for medicinal use, and the initial pre-test revealed a relatively high content of polysaccharides in Radix ranunculus ternati. In this experiment, polysaccharides were extracted from Radix ranunculus ternati, and its effect on in vitro-cultured human breast cancer MCF-7 cell line was studied, so as to find effective antitumor parts of Radix ranunculus ternati and their mechanisms of action, and thus provide a theoretical basis for its clinical treatment of cancer.

\section{Materials and Methods}

\section{Drugs and reagents}

Radix ranunculus ternati (provided by the College of Pharmacy of our university, origin: Xinyang, Henan) was identified as the dried root tuber of Ranunculaceae herb Ranunculus ternatus Thunb by Professor Wang Jianan. The number is 2012-1.226. RPMI 1640 medium (GIBCOBRL); MTT (Sigma); fluorouracil (Hengrui Medicine Co., Ltd., Jiangsu); glucose reference substance and other reagents were all of analytical grade. 


\section{Main instruments}

http://dx.doi.org/10.4314/ajtcam.v10i6.6

The instruments included AE31 inverted phase contrast microscope (Motic), SW-CJ-IF clean bench (Suzhou Purification Equipment Factory), fully automatic microplate reader (Mod550, BioRad), low-temperature refrigerated centrifuge (Eppendorf, Germany), electronic balance (Sartorius AG, Beijing), and blood counting chamber (Qiujing Biochemical Instrument Factory, Shanghai).

\section{Human breast cancer MCF-7 cell lines}

The cell lines were provided by the Department of Pharmacology, Zhengzhou University, China.

\section{Methods}

\section{Extraction and purification of polysaccharides from Radix ranunculus ternati}

Polysaccharides were extracted and purified by water extraction, ethanol precipitation and svega method (Folkman J, 1971). 100 g of dried Radix ranunculus ternati powder was accurately weighed placed in a Soxhlet extractor and successively reflux extracted with petroleum ether $\left(30^{\circ} \mathrm{C} \sim 60\right.$ ${ }^{\circ} \mathrm{C}$ ), diethyl ether and ethanol for $4 \mathrm{~h}$. After the solvent was evaporated to dryness, the residue was again reflux extracted with water for 4 h, then concentrated to half volume under reduced pressure, decolorized and filtered by addition of $0.1 \%$ activated carbon. The filtrate was added with $95 \%$ ethanol to make the ethanol content in the solution $80 \%$. It was allowed to stand overnight, and filtered. The residue was washed repeatedly with diethyl ether and anhydrous ethanol. Crude polysaccharides of Radix ranunculus ternati were obtained, and were dissolved in water into a $10 \%$ sugar solution and deproteinized by svega method. The aqueous solution was low temperature freeze-dried to obtain total polysaccharides of Radix ranunculus ternati for later use.

Inhibitory effect of Radix ranunculus ternati polysaccharides on proliferation of human breast cancer MCF-7 cell lines MCF-7 cells in the logarithmic growth phase were taken and seeded in 96 -well plates at $5 \times 10^{3}$ cells per well and cultured overnight. Then, saponin was added to make the mass concentrations 12.5, 25.0, 50.0, 100, 200 and $400 \mathrm{mg} / \mathrm{L}$. Each concentration had three parallel wells, and blank control group and 5-Fu group (50 $\mathrm{mg} \cdot \mathrm{L}^{-1}$ ) were also set up. The cells were cultured for $48 \mathrm{~h}$, then added with $5 \mathrm{~g} / \mathrm{L} \mathrm{MTT}$, and cultured for another $4 \mathrm{~h}$. Culture liquid was completely discarded, and each well was added with $150 \mu \mathrm{L}$ of DMSO. After shaking gently, optical density (OD) value of each well was measured using a microplate reader (wavelength of $570 \mathrm{~nm}$ ). Average OD value of each group was taken, dose-effect curve was drawn, and cell growth inhibition rate was calculated, thus:

Inhibition rate $(\%)=(1-$ average OD value of drug well $/$ average OD value of control well $) \times 100 \%$.

\section{Flow cytometry (FCM)}

After $72 \mathrm{~h}$ action of Radix ranunculus ternati polysaccharides $(500 \mathrm{mg} / \mathrm{L})$ on MCF-7 cells, the cells were collected. They were repeatedly washed in PBS, centrifuged, and then fixed at $4^{\circ} \mathrm{C}$ with $75 \%$ ethanol overnight. $200 \mu \mathrm{L}$ of RNA enzyme solution $(5 \mathrm{~g} / \mathrm{L})$ was added, $37^{\circ} \mathrm{C}, 30$ min. The reaction was terminated in an ice bath and cell suspension was stained by addition of PI $(50 \mathrm{mg} / \mathrm{L}), 4^{\circ} \mathrm{C}, 30 \mathrm{~min}$, and the cell cycle was determined by FCM (wavelength of $488 \mathrm{~nm}$ ).

\section{Measurement of natural killer (NK) cell activity}

Volume fraction of spleen cells was $1 \times 10^{7} / \mathrm{mL}$, volume fraction of MCF-7 target cells was $5 \times 10^{5} / \mathrm{ml}$, and the effector- target was $20: 1$. $100 \mu \mathrm{L}$ of effector and target cells were taken respectively. Effector cells were replaced by culture medium in the natural release group, and by $1 \%$ NP40 in the maximum release group. After $2 \mathrm{~h}$ incubation at $37^{\circ} \mathrm{C}$, the effector-target reaction was terminated, and the cells were centrifuged at $1500 \mathrm{r} / \mathrm{min}$ for $5 \mathrm{~min}$. Then, the supernatant was taken and added in a 96-well plate at $100 \mathrm{~L}$ per well, and pre-heated at $37^{\circ} \mathrm{C} .100 \mu \mathrm{L}$ of substrate solution was added to each well, and the plate was allowed to stand at room temperature for $10 \mathrm{~min}$, before $30 \mu \mathrm{L}$ of $0.1 \mathrm{~mol} / \mathrm{L}$ citric acid was added to terminate the enzymatic reaction. OD value was measured at $570 \mathrm{~nm}$, and natural killing rate was calculated:

Natural killing rate $(\%)=($ OD value of sample release - OD value of natural release $) /($ OD value of maximum release - OD value of natural release $) \times$ $100 \%$. 
http://dx.doi.org/10.4314/ajtcam.v10i6.6

\section{Statistical methods}

The experimental data were analyzed using SPSS 13.0 software. Comparisons between two groups were performed using t-test, and pairwise

comparisons among groups were performed by one-way ANOVA.

\section{Results}

Inhibitory effect of Radix ranunculus ternati polysaccharides on MCF-7 cell lines

Inhibitory effects of different doses of Radix ranunculus ternati polysaccharides on MCF-7 cell lines are shown in Table. 1. Each Radix ranunculus ternati polysaccharides dose group could inhibit the growth of human breast cancer MCF-7 cell lines in varying degrees. The greater the concentration of polysaccharides, the more evident the inhibitory effect, and this showed an apparent dose-dependency. When the polysaccharide concentration was 50.0-200 mg/L, the treatment group and the blank control group presented a significant difference $(\mathrm{P}<0.05$ or $\mathrm{P}<0.01)$.

Table 1: Inhibitory effects of different doses of Radix ranunculus ternati polysaccharides on MCF-7 cell lines

\begin{tabular}{cccc}
\hline Group & Concentration $(\mathrm{mg} / \mathrm{L})$ & OD value & Inhibition rate $(\%)$ \\
\hline Blank control group & - & $0.414 \pm 0.023$ & - \\
5-Fu group & 50.0 & $0.186 \pm 0.018$ & 55.07 \\
$\begin{array}{l}\text { Radix ranunculus ternati } \\
\text { polysaccharides group 1 }\end{array}$ & 12.5 & $0.388 \pm 0.026$ & 6.28 \\
$\begin{array}{l}\text { Radix ranunculus ternati } \\
\text { polysaccharides group 2 }\end{array}$ & 25.0 & $0.341 \pm 0.027$ & 17.63 \\
$\begin{array}{l}\text { Radix ranunculus ternati } \\
\text { polysaccharides group 3 }\end{array}$ & 50.0 & $0.282 \pm 0.019^{*}$ & 31.88 \\
Radix ranunculus ternati & & & 37.92 \\
$\begin{array}{l}\text { polysaccharides group 4 } \\
\text { Radix ranunculus ternati } \\
\text { polysaccharides group 5 }\end{array}$ & 100.0 & $0.257 \pm 0.021^{* *}$ & 46.14 \\
\hline
\end{tabular}

Comparison with the control group: "*" indicates $\mathrm{P}<0.05$, "**" indicates $\mathrm{P}<0.01$

\section{Flow cytometry (FCM) results}

Flow cytometry results showed that after 48 and $96 \mathrm{~h}$ action of the Radix ranunculus ternati polysaccharides with a concentration of 500 $\mathrm{mg} / \mathrm{L}$ on MCF-7 cells, apoptosis rates were $(8.7 \pm 1.2) \%$ and $(16.5 \pm 1.7) \%$ respectively. After $72 \mathrm{~h}$ action of the polysaccharides, a significant sub-G1 peak was present in MCF-7 cells. Compared with the blank control group, the percentage of G2/M phase cells increased (blank control group 3.53\%, Radix ranunculus ternati polysaccharides group 12.54\%), the percentage of G0/G1 phase cells declined (blank control group $67.51 \%$, Radix ranunculus ternati polysaccharides group, $47.35 \%$ ). The percentage of S phase cells were similar, and the cells were arrested in the G2/M phase. The apoptosis rate of Radix ranunculus ternati polysaccharides group was $9.62 \%$.

\section{NK cell activity assay results}

The effects of different doses of Radix ranunculus ternati polysaccharides on NK cell activity are shown in Table. 2. The different doses of Radix ranunculus ternati polysaccharides could all increase the killing rate of NK cells on human breast cancer MCF-7 cell lines in varying degrees, and the higher the concentration, the stronger the effect. 
http://dx.doi.org/10.4314/ajtcam.v10i6.6

Table 2: Effects of Radix ranunculus ternati polysaccharides on NK cell activity

\begin{tabular}{ccc}
\hline Group & Dose $(\mathrm{g}$ crude drug $/ \mathrm{kg})$ & NK cell's killing rate $(\%)$ \\
\hline $\begin{array}{c}\text { Blank control group } \\
\text { Radix ranunculus ternati } \\
\text { polysaccharides low-dose group } \\
\text { Radix ranunculus ternati } \\
\text { polysaccharides medium-dose } \\
\quad \text { group }\end{array}$ & 3.2 & $11.05 \pm 1.64$ \\
$\quad$ & 6.4 & $27.63 \pm 3.55$ \\
$\begin{array}{l}\text { Radix ranunculus ternati } \\
\text { polysaccharides high-dose group }\end{array}$ & 12.8 & $30.71 \pm 4.29$ \\
\hline
\end{tabular}

\section{Discussion}

Polysaccharides widely exist in the plants of the natural world, which are especially one of the active ingredients in a variety of Chinese medicines. They are characterized by having various biological activities, such as anti-tumor, anti-inflammatory, anticoagulant, anti-viral, anti-radiation, hypoglycemic and hypolipidemic activities, which makes them a relatively ideal immunopotentiator. Clinical researches have found out that they can inhibit the production of tumor necrosis factor (Li et al., 2004; Zhang et al., 2004; Cao et al., 1999; Li et al., 1999). One study has considered from the perspective of trace elements and health that $\mathrm{Cu} / \mathrm{Zn}$ ratio increases in serum of cancer patients, while the $\mathrm{Cu} / \mathrm{Zn}$ ratio trend of Radix ranunculus ternati polysaccharides is opposite to that of cancer patients, and therefore may help regulate the $\mathrm{Cu} / \mathrm{Zn}$ balance of patients, thereby exerting an anti-cancer effect (Quan et al., 1997; Wang et al., 1997; Zheng et al., 1997). Another study (Zhou et al., 1995; Zhang et al., 1995; Xu et al., 1995) demonstrated that the $70 \%$ ethanol extract of Radix ranunculus ternati has a strong inducing effect on the production of tumor necrosis factor (TNF).

In this study, the total polysaccharides of Radix ranunculus ternati were extracted and purified by water extraction, ethanol precipitation and svega method. The in-vitro anti-breast cancer effect of the extract was preliminarily studied. The result showed that the Radix ranunculus ternati polysaccharides have different degrees of effects on the growth of human breast cancer MCF-7 cell lines, and the differences were significant compared with the blank control group. This study further confirmed by MTT and FCM that the in vitro anti-tumor mechanism of action may be through inhibition of cell proliferation, induction of cell apoptosis and arrest of cell cycle, thereby inhibiting DNA synthesis and tumor cell division. This study also confirmed that the different doses of Radix ranunculus ternati polysaccharides can significantly improve the killing rate of NK cells on tumor cells and improve immune function. Radix ranunculus ternati resource is rich in China. Further studies of its anti-breast cancer effective constituents and their structures and exact mechanisms of action will be of important significance.

\section{References}

1. Cao JH, Li H. (1999) Research progress in polysaccharide immunomodulators. Chinese Journal of Biochemical Pharmaceutics, 20(2): 104-106

2. Flora of China Editorial Committee. (1979) Chinese Academy of Sciences. Flora of China (Vol. 28), Beijing: Science Press 302-303

3. Folkman J. (1971) Tumor angiogenesis: therapeutic implications. N Engl J Med, 285(5): 1182-1186

4. Institute of Materia Medica, Chinese Academy of Medical Sciences. (1982) Chinese Materia Medica, Beijing: People's Medical Publishing House, 2: 527-528

5. Iriky. (1972) Furutas sugars of Ranunculus ternatus Var glaber I . Nihon Nogei Kagaku Kaishi 46: 411-412

6. Iriky. (1975) Furutas sugars of Ranunculus ternatus Var glaber I . Nihon Nogei Kagaku Kaishi, 49: 7-10

7. Li J, Zhang CQ. (2004) Recent advances in immunoregulatory and antitumoral activities of polysaccharides. Chinese Journal of Veterinary Medicine, 40(11): 31-33

8. National Herbal Compendium Writing Group. (1982) National Herbal Compendium, Beijing: People's Medical Publishing House, 1: $791-793$

9. Pharmacopoeia Commission of the Ministry of Health of the People's Republic of China. (2000) Pharmacopoeia of the People's Republic of China, Guangdong, Guangdong Science and Technology Press, 1: 260-261 
Sun et al., Afr J Tradit Complement Altern Med. (2013) 10(6):439-443

http://dx.doi.org/10.4314/ajtcam.v10i6.6

10. Quan SC, Wang XZ. (1997) Analysis of trace elements of Chinese medicine Radix ranunculus ternati. Studies of Trace Elements and Health, 14(2): 29-30

11. Xie ZW, Yu YD. (1996) Institute of Chinese Materia Medica of the Chinese Academy of TCM. Dictionary of the Names of Chinese Herbal Medicines, Beijing: People's Medical Publishing House, 2: 1621-1622

12. Yang JX. (1981) Anticancer Chinese Herbal Preparations, Beijing: People's Medical Publishing House, 173-174

13. Zhou WS, Wu LC. (1997) Summary of Treatment of Malignant Lymphomas. Zhejiang Journal of Traditional Chinese Medicine, 32(8): 345-346

14. Zhou L, Zhang W, Xu J. (1995) Effect of active constituents of Radix ranunculus ternati on induction of tumor necrosis factor. Acta Academiae 